\title{
Feasability of a Frameless Brain Biopsy System for Companion Animals Using Cone-Beam CT-Based Automated Registration
}

\section{Felix Meneses ${ }^{1 *}$, Arianna Maiolini ${ }^{2}$, Franck Forterre ${ }^{3}$, Anna Oevermann ${ }^{4}$ and Daniela Schweizer-Gorgas ${ }^{1}$}

${ }^{1}$ Division of Clinical Radiology, Department of Clinical Veterinary Medicine, Vetsuisse-Faculty, University of Bern, Bern, Switzerland, ${ }^{2}$ Division of Neurology, Department of Clinical Veterinary Medicine, Vetsuisse-Faculty, University of Bern, Bern, Switzerland, ${ }^{3}$ Division of Small Animal Surgery, Department of Clinical Veterinary Medicine, Vetsuisse-Faculty, University of Bern, Bern, Switzerland, ${ }^{4}$ Neurocenter, Department of Clinical Research and Veterinary Public Health, Vetsuisse-Faculty, University of Bern, Bern, Switzerland

The aim of the present study was to evaluate the use of a novel intraoperative cone-beam computed tomography (CBCT)-based automated registration system for frameless stereotactic brain biopsy in companion animals. An experimental cadaveric study evaluated thalamic and piriform lobe target site needle placement error in three dogs and three cats without a history of intracranial disease. Diagnostic accuracy and diagnostic yield were prospectively evaluated in twenty-four client-owned dogs and four cats with intracranial disease. Twenty-one procedures were performed post mortem (eighteen dogs and three cats), and seven biopsy procedures were performed in alive patients (six dogs and one cat). Procedural duration was evaluated in ten post mortem and four living patients. Outcome was evaluated in six dogs and one cat. In dogs, the calculated median needle placement error was $1.8 \mathrm{~mm}$ (range $0.71-2.84 \mathrm{~mm}$ ) and $1.53 \mathrm{~mm}$ (range 1.45-1.99 mm) for piriform lobe and thalamus target sites, respectively. In cats, the calculated median needle placement error was $0.79 \mathrm{~mm}$ (range $0.6-1.91 \mathrm{~mm}$ ) for the piriform lobe target site and $1.29 \mathrm{~mm}$ (range $0.47-2.69 \mathrm{~mm}$ ) for the thalamic target site. The diagnostic yield was $96.4 \%$ (95\% Cl 0.81-0.99), the diagnostic accuracy was 94.4\% (95\% Cl 0.72-0.99). Median total procedural duration for post mortem biopsies was $57.5 \mathrm{~min}$ (range 41-69 min). Median total procedural duration for intra vitam biopsies was $122.5 \mathrm{~min}$ (range 103-136 min). Three dogs were discharged 1 day after biopsy and one dog after 6 days. Two dogs and one cat were euthanized 24 and $48 \mathrm{~h}$ after biopsy. Intraoperative CBCT-based automated image registration for frameless stereotactic biopsies in companion animals is capable of providing diagnostic brain biopsy specimens independent of skull size and morphology with diagnostic yield and accuracy comparable to published values for diverse frameless and frame-based stereotaxy systems used in veterinary medicine. Duration of the procedure is not negatively affected and within the published range with other systems. Mobile intraoperative CBCT-based registration combined with neuronavigation delivers diagnostic brain biopsies in companion animals.

Keywords: СВСТ-based automated registration, brain biopsy, frameless, dogs, cats 


\section{INTRODUCTION}

Recent advances in imaging technology and therapeutic modalities have led to significant improvements in the treatment of intracranial disease in companion animals (1). However, a histological diagnosis before treatment remains the exception, and the majority of evidence-based studies favoring one treatment modality over another are based on a presumptive diagnosis (2).The ability of magnetic resonance imaging (MRI) to differentiate vascular, inflammatory, and neoplastic disease is deceptively low (3-5). In people, the discordance of histological and imaging diagnosis based on MR imaging varies from 16 to $30 \%(6,7)$ leading to treatment changes in $16-27 \%(8)$. Therefore, an aggressive treatment with concomitant side effects should be based on brain biopsies (9). A wide variety of stereotactic brain biopsy systems are currently successfully employed in veterinary clinical practice (10-21). Brain biopsy systems with stereotactic guidance are either frame-based or frameless, with the former considered to be the standard of care due to its excellent targeting precision. Frame-based stereotaxy uses a rigid skull-mounted frame that functions as a coordinate system to which any point inside the brain can be referenced. Frameless stereotaxy dispenses of the bulky frame and uses anatomical landmarks or skin fiducials to register image coordinates to patient coordinates instead. The advantages of frameless stereotaxy include minimally invasive technique and reduced post-operative infection risk, improved target visualization and accessibility, flexibility to sample multiple targets, and reduced procedure time (22). In conjunction with adjustable rigid aiming devices, target accuracy and diagnostic yield are nowadays equivalent to frame-based stereotaxic systems $(22,23)$.

In recent times, compact mobile computed tomography (CT) imaging units combined with navigation systems are increasingly used for precision neurosurgical and orthopedic interventions $(22,24)$. Newer units are equipped with an integrated indicator box that allow intraoperative image acquisition with immediate and automatic registration of the patient to the images (25, 26). In veterinary medicine utilization of a mobile conebeam CT (CBCT) system has been described for computerassisted surgery in horses (24). Adapting this system for brain biopsies in dogs and cats has the potential to simplify brain biopsy procedures, decreasing procedure times and registration inaccuracies by eliminating the need for patient transport between the imaging and operating rooms as well as userdependent patient registration. Data regarding needle placement error, diagnostic yield, diagnostic accuracy, procedural time, and outcome with this system in this setting are currently lacking. The aim of the present study was to report our experience adapting an intraoperative CBCT-based automated registration system for frameless brain biopsies in companion animals. We hypothesized that needle placement error, diagnostic yield, and diagnostic accuracy would be comparable to previously reported brain biopsy systems and that procedural times would be shorter.

\section{MATERIALS AND METHODS}

The first part of the study consisted of a prospective experimental cadaver study in dogs and cats to test the needle placement error. The second part consisted of a prospective study in dogs and cats where an intracranial lesion was diagnosed by MRI or $\mathrm{CT}$ and a brain biopsy was conducted, either in alive patients or post mortem. All interventions were performed with signed owner consent.

\section{Experimental Cadaver Study}

Needle placement error was tested in three dogs and three cats without a history of intracranial disease that were euthanized for reasons unrelated to the study. A 3D T1-weighted gradient echo sequence (TE $6.91 \mathrm{~ms}$, TR $25 \mathrm{~ms}$, FA $30^{\circ}$, matrix between $320 \times 320$ and $576 \times 576$, FOV between 56.67 and $66 \mathrm{~mm}$, slice thickness $1 \mathrm{~mm}$ ) was acquired using a $1.0 \mathrm{~T}$ unit within $24 \mathrm{~h}$ of euthanasia. The cadavers were transported to the operating room and positioned in sternal recumbency on a carbon table. Memory foam pads were used to stabilize the trunk and neck. Heads were clipped and the maxillary dental arcades firmly secured with dental putty (President, Coltene, Altstatten, Switzerland) to a custom-made perforated bite plate with an attached reference array equipped with infrared reflectors (Medtronic Schweiz AG, Münchenbuchsee, Switzerland). A single high resolution 26 second head scan was acquired with a volume of $22 \times 22 \times$ $17 \mathrm{~cm} 3$ and a pixel size of $0.415 \mathrm{~mm} 2$ (O-arm, Medtronic Schweiz AG, Münchenbuchsee, Switzerland) with both reference array and indicator box of the scanner in the field of view of the infrared navigation camera of the dedicated workstation (StealthStation S7, Medtronic Schweiz AG, Münchenbuchsee, Switzerland) (Figure 1). The volumetric acquisition was then transferred to the workstation for automated patient registration and automated image fusion (StealthViz, Medtronic Schweiz AG, Münchenbuchsee, Switzerland) with the preloaded MRI 3D T1-weighted MRI series. Correct alignment of fused images was evaluated visually on the workstation. Target points and trajectories were planned on the merged dataset (Framelink 5.0, Medtronic Schweiz AG, Münchenbuchsee, Switzerland). In each cadaver, one target site was set in the left piriform lobe and one in the right thalamus. Entry sites were planned to be perpendicular to the skull, with resultant trajectories avoiding sulci and the ventricular system. Throughout the procedure the navigation camera was positioned such that the reflective spheres of the reference array and navigable instruments were visible at all times. Registration accuracy was controlled regularly on anatomical landmarks. An articulating instrument holder (Vertek single-lever articulating support arm, Medtronic Schweiz AG, Münchenbuchsee, Switzerland) attached to the surgical table and a navigable pointer (Vertek, Medtronic Schweiz AG, Münchenbuchsee, Switzerland) were then adjusted with realtime visual feedback to reproduce the planned trajectory in the navigable space. Once the position corresponded to the planned trajectory, the articulating arm was locked in position. A standard surgical rostrotentorial approach was used to expose the skull. 


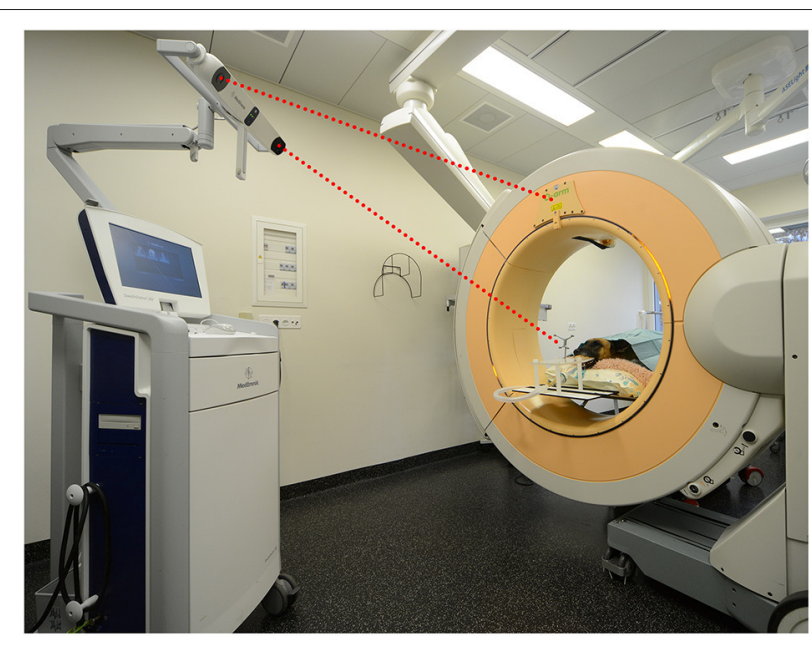

FIGURE 1 | Set up of the mobile cone-beam computed tomography and navigation system in the operating room showing a dog cadaver in sternal recumbency. The head has been secured to the bite plate. For image registration to the patient's anatomy, a head scan is performed during which the infrared camera must see the reference array and indicator box of the scanner (red dotted lines).

A high-speed pneumatic drill with a $3 \mathrm{~mm}$ burr head was used to create a burr-hole and the dura mater was incised with a dedicated dura perforator or a $18 \mathrm{G}$ hypodermic needle with bent tip. The navigable pointer was then exchanged for a navigable, $2 \times 200 \mathrm{~mm}$, Sedan-type brain biopsy needle (model 9733068, Medtronic Schweiz AG, Münchenbuchsee, Switzerland). This biopsy needle is equipped with two spherical infrared reflectors that allow direct feedback of needle tip and biopsy window positions by the navigation system. The biopsy needle was then advanced under real-time visual feedback toward the planned target site, and a second volume acquisition with the brain biopsy needle in place was performed. After merging the images, the mean needle tip deviation was measured in transverse, dorsal, and sagittal planes from the superimposition of the planned trajectories with the actual needle position on the workstation. The Euclidean distances were then determined using the formula:

$$
\text { Error }=\sqrt{ }\left[(\Delta x)^{2}+(\Delta y)^{2}+(\Delta z)^{2}\right]
$$

\section{Clinical Patients}

Twenty-four client-owned dogs and four cats presented to the neurology service of the Vetsuisse-Faculty Bern during the period between July 2017 and July 2020 that underwent brain biopsy as part of the diagnostic work-up of clinical signs referable to intracranial disease were prospectively included in this study. Signalment, presenting complaint, neuroanatomical localization based on neurological exam, and outcome were recorded. General anesthesia for dogs and cats undergoing intra vitam biopsy was performed by the anesthesiology service and protocols varied based on their individual assessment of each patient. The heads of animals were clipped, aseptically prepared, covered, and patients subsequently transported to the operating room. The animals were then positioned and immobilized as described for the cadaveric study. Following the $\mathrm{O}$-arm acquisition a second surgical skin preparation was done, and sterile draping started while automated patient registration, automated image fusion with a preloaded preoperative contrast enhanced CT or 3D T1-weighted MRI series, and trajectory planning were done on the workstation in the operating room (Figure 2). Biopsy trajectory planning was performed on the merged dataset defining both target and entry sites depending on lesions location and MRI features (Figure 3A). As previously described, trajectories were planned perpendicular to the skull avoiding sulci and ventricular system, except in animals with intraventricular lesions. Target sites were selected to include contrast enhancing areas of the lesions when present, avoiding cystic, necrotic, or hemorrhagic areas. The articulating instrument holder was attached to the surgical table on the same side of the brain lesion. Instrument holder and navigable pointer were then adjusted with real-time visual feedback and standard surgical rostro- or caudotentorial approaches and dura mater incision were performed as described before. The precalibrated brain biopsy needle was then advanced under real-time visual feedback until the biopsy window was centered on the planned target (Figure 3B). Two to six biopsies were taken at different depths and orientations, with the number of biopsies depending on the tissue yield (Figure 3C). The bone defect was left uncovered, muscles and skin were adapted following standard closing procedures. Dogs and cats undergoing post mortem biopsy were prepared and positioned as for the cadaveric study and biopsies were taken as for the intra vitam patients.

\section{Procedural Duration Measurements}

Minor adjustments involving optimization of the spatial disposition of the CBCT and workstation in the operating room and of the image-guided articulating instrument holder on the surgical table were performed during the first three intra vitam procedures. Thereafter, to investigate procedural duration five time intervals were determined and recorded for patient positioning, including CBCT image acquisition in the operating room, trajectory planning, biopsy needle alignment, surgical approach, and biopsy retrieval in four intra vitam and ten post mortem biopsy procedures (Figure 4). The total procedural duration defined as start of patient positioning to end of biopsy specimen retrieval resulted from adding all intervals.

\section{Histopathological Examination}

Biopsy specimens were flushed into biopsy cassettes or nylon mesh biopsy bags. Biopsies and brains were fixed by immersion in $10 \%$ buffered formalin and routinely processed for paraffin embedding. Four micrometer thick sections were stained with hematoxylin and eosin. Evaluation included identification of cell types, extent and location of the infiltration, presence of edema, hemorrhage, and necrosis. Tumor grading was based on number of mitotic figures, cell density, and cell anaplasia according to the human 2007 WHO classification of tumors of the central nervous system and current veterinary literature (27-30). Diagnostic yield was defined as the number of biopsy procedures that allowed a histopathologic diagnosis $(19,31)$. Diagnostic accuracy was 

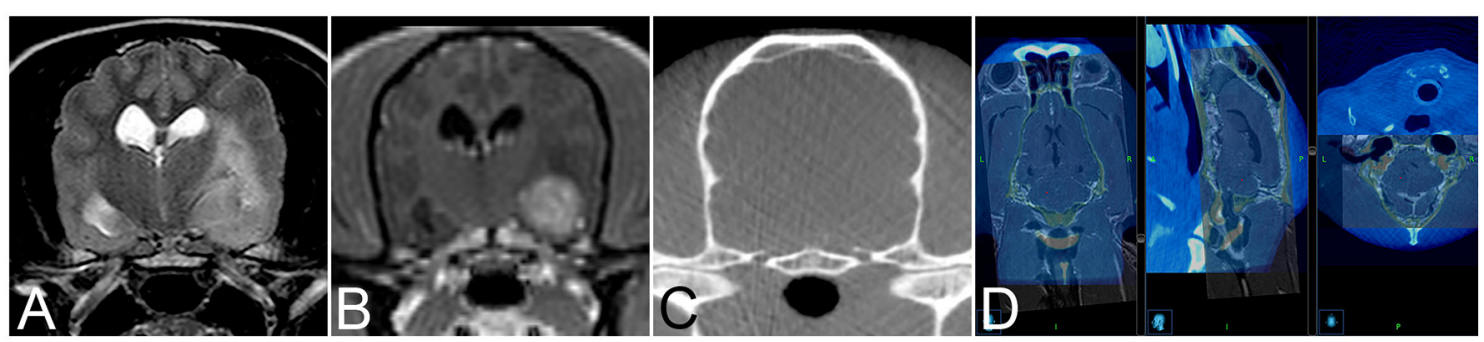

FIGURE 2 | Transverse T2-weighted (A) and T1-weighted contrast enhanced (B) image and of an 11-year-old female spayed Poodle with biopsy proven vasculitis and meningoencephalitis of unknown origin. Corresponding intraoperative cone beam computed tomography (CBCT) image (C) for image fusion. (D) Example of image fusion of the CBCT images with magnetic resonance images of a 9-year-old female spayed German Shepherd Dog with a biopsy proven WHO grade II cerebellar diffuse astrocytoma.
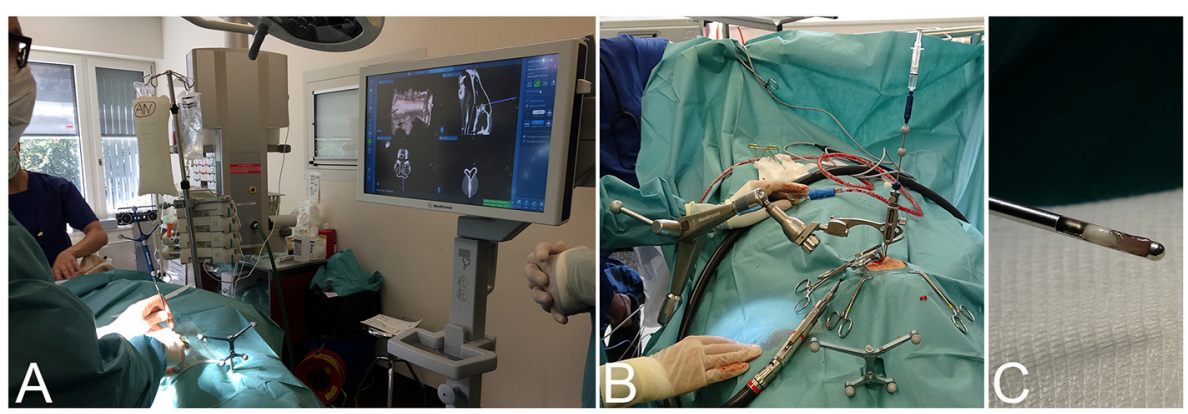

FIGURE 3 | Intraoperative workflow for navigated frameless stereotactic brain biopsy. (A) Finding the optimal skin incision site to match the entry point using the navigable pointer with real-time visual feedback on the system's surgeon monitor. (B) After dura opening, the navigable biopsy needle has been advanced to the target depth under visual guidance. (C) Example of a brain biopsy specimen taken from the periphery of a lesion.

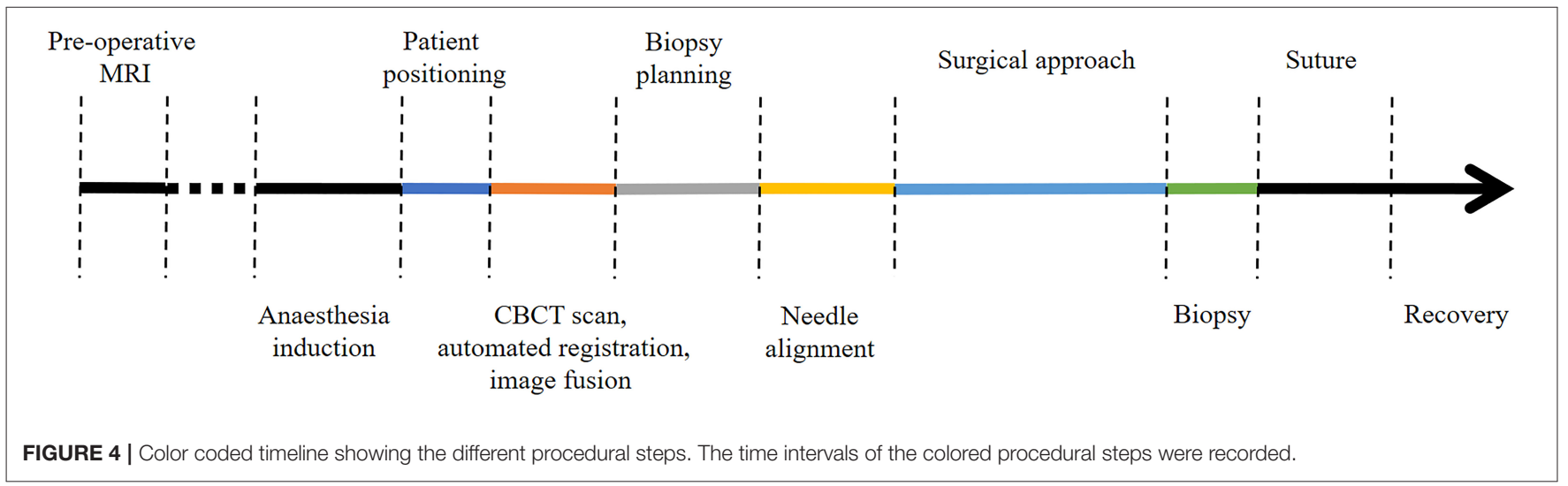

defined as the number of biopsy procedures that gave the same diagnosis as necropsy specimen examination. In the latter cases, the brains were removed from the skull immediately after the post mortem procedure.

\section{Statistical Analyses}

Needle placement error data is reported as median and range. The correlation of experience with time in both intra vitam and post mortem procedures was evaluated with the Spearman's rank correlation coefficient, the influence of intra vitam vs. post mortem biopsies with the Kruskal-Wallis oneway ANOVA on ranks. $P$ values $<0.05$ were considered statistically significant. All analyses were performed using commercial statistical software (NCSS version 12.0.2, Kaysville, UT, USA).

\section{RESULTS}

Needle placement error was tested in six cadavers, three male neutered dogs (one French Bulldog, one American Bulldog, and one cross breed) with a median body weight of $21 \mathrm{~kg}$ (range: 
15-30), and three male neutered cats (two European shorthair, and one Maine Coon) with a median body weight of $5 \mathrm{~kg}$ (range: 4.3-5.2) (Table 1). Median piriform and thalamic target site depth in dogs was $54 \mathrm{~mm}$ (range $49.5-64.9 \mathrm{~mm}$ ) and $49.4 \mathrm{~mm}$ (range 44-62.5 mm). Median piriform and thalamic target site depth in cats was $31.6 \mathrm{~mm}$ (range $23.9-32.2 \mathrm{~mm}$ ) and $23.5 \mathrm{~mm}$ (range 20.5-25.9 mm). In dogs, the calculated median needle placement error was $1.8 \mathrm{~mm}$ (range $0.71-2.84 \mathrm{~mm}$ ) and $1.53 \mathrm{~mm}$ (range 1.45-1.99 $\mathrm{mm}$ ) for piriform lobe and thalamus target sites, respectively. In cats, the calculated median needle placement error was $0.79 \mathrm{~mm}$ (range $0.6-1.91 \mathrm{~mm}$ ) for the piriform lobe target site and $1.29 \mathrm{~mm}$ (range $0.47-2.69 \mathrm{~mm}$ ) for the thalamic target site.

Frameless image-guided stereotactic brain biopsies were performed in twenty-eight animals. Twenty-one procedures were performed post mortem (eighteen dogs, three cats), and seven biopsy procedures were performed in alive patients (six dogs, one cat). Post mortem biopsies were performed within $8 \mathrm{~h}$ of euthanasia. Biopsy procedures in alive animals were performed between three to seven days after initial diagnosis. In all but one animal, the intracranial lesion was diagnosed on MRI, in one dog (Patient number 15) a CT of the head was performed. Demographics and lesion characteristics are summarized in Table 1. Dog breeds included Boxer (3), French Bulldog (3), Bolonka Zwetna (2), Golden Retriever (2), Bernese Mountain Dog (1), Border Terrier (1), Boston Terrier (1), Collie (1), Dachshund (1), German Shepherd (1), Labrador Retriever (1), Magyar Viszla (1), Poodle (1), Portuguese Water Dog (1), Shih Tzu (1), and Cross Breed (3). Three dogs were intact female, eight spayed female, eight intact male, and five neutered male. Cat breeds included European Shorthair (2), Birman (1), and British shorthair (1). All cats were female spayed. The median age was 8 years (range 1-12 years) in dogs and 10 years (range 5-17 years) in cats. The median body weight was $19.5 \mathrm{~kg}$ (range $4-55 \mathrm{~kg}$ ) in dogs and $4.4 \mathrm{~kg}$ (range $3.7-4.8 \mathrm{~kg}$ ) in cats. Canine brain lesions were intra-axial in fifteen cases, extra-axial in three, and both intra- and extra-axial in six. Feline brain lesions were intra-axial and extra-axial in two cases each. The median maximum lesion diameter was $18.8 \mathrm{~mm}$ in dogs (range 11$32.6 \mathrm{~mm}$ ) and $17.25 \mathrm{~mm}$ (range $11.7-15.3 \mathrm{~mm}$ ) in cats. In all animals but two dogs, where MRI was performed post mortem, the lesions showed contrast enhancement on MRI $(25 / 28)$ and CT (1/1).

The median target site depth in dogs was $38 \mathrm{~mm}$ (range 20.1$60 \mathrm{~mm}$ ) and $30.35 \mathrm{~mm}$ in cats (range $17.4-46.1 \mathrm{~mm}$ ). Biopsies were taken along a single trajectory in all cases. Surgical approach was left rostrotentorial in thirteen cases, right rostrotentorial in twelve cases, and caudotentorial in two cases. The median number of biopsies was four in dogs (range 2-6 biopsies) and four in cats (range 3-4 biopsies).

Gross pathologic specimens were available for comparison in $18 / 28$ animals. Biopsies allowed a histopathologic diagnosis in $27 / 28$ animals (96.4\% 95\% CI 0.81-0.99). The single failed biopsy procedure was due to insufficient amount of tissue. The biopsy diagnosis was confirmed by pathology specimen histopathology in seventeen of eighteen cases (94.4\%, 95\% CI 0.72-0.99).

\section{Procedural Duration}

Time intervals were recorded for four procedures in living animals and ten post mortem biopsy procedures (Figure 5) Median total procedural duration for intra vitam biopsies was $122.5 \mathrm{~min}$ (range $103-136 \mathrm{~min}$ ). Median total procedural duration for post mortem biopsies was $57.5 \mathrm{~min}$ (range 41 $69 \mathrm{~min}$ ). The Spearman's rank correlation test showed that with experience there was a significant shortening of the total procedural duration $(p=0.03), \mathrm{O}$-arm acquisition, merge and automated registration $(p=0.02)$, and biopsy planning for the post mortem biopsies $(p=0.04)$. Kruskal-Wallis one-way ANOVA on ranks showed total procedure duration $(p=0.005)$, patient positioning $(p=0.009)$, needle alignment $(p=0.03)$, and surgical approach $(p=0.02)$ for post mortem biopsies to be significantly shorter than for intra vitam biopsies (Figure 5).

\section{Outcome of Intra Vitam Biopsy Procedures}

Seven biopsy procedures were performed in living patients. Two dogs were euthanized within $24 \mathrm{~h}$ after the biopsy procedure because of failure to regain spontaneous respiration. Both dogs were comatose and showed signs of increased intracranial pressure on MRI prior to the biopsy procedure. Despite associated high surgical risk, biopsies had been taken at the owner's request. One cat developed decompensation of subclinical hypertrophic cardiomyopathy that did not respond to medical treatment and was euthanized $48 \mathrm{~h}$ after biopsy procedure. Three dogs were discharged 1 day after the biopsy, one dog after 6 days (Table $\mathbf{1}$ ).

\section{DISCUSSION}

Diagnosis and specific treatment planning for intracranial disease requires tissue sampling and histopathologic examination (6). Inaccurate diagnosis may lead to inappropriate therapy and incorrect prognosis. Likewise, meaningful evaluation of new treatment protocols should ideally be based on histologic diagnosis in order to avoid erroneous conclusions (31). Tissue sampling is not routinely performed in companion animals due to lack of equipment and expertise, technical difficulties associated with the variable skull morphology, size and thick masticatory muscle cover, as well as owner perception of the risks and high costs associated with the procedure. To overcome part of these hurdles and in an attempt to simplify the brain biopsy procedure in dogs and cats, we tested an intraoperative CBCTbased automated registration system for frameless brain biopsies that obviates user-dependent patient registration and transport between the imaging and operating suites, two intermediate steps that have the potential to decrease target accuracy and prolong procedural time.

Frameless stereotaxy patient registration based on anatomical or skin fiducials has been shown to produce comparable results in people but are considered to be highly operator dependent. Modern mobile intraoperative computed tomography systems allow user-independent immediate and automatic patient registration with high accuracy. Navigated surgery using the $\mathrm{O}$-arm in combination with the Stealth Station has been 


\begin{tabular}{|c|c|c|c|c|c|c|c|c|c|c|c|c|c|c|}
\hline $\begin{array}{l}\text { Pat. } \\
\text { Nr. }\end{array}$ & Species & Breed & $\begin{array}{l}\text { Age } \\
\text { (y) }\end{array}$ & Sex & $\begin{array}{l}\text { Body } \\
\text { weight } \\
\text { (kg) }\end{array}$ & IV/PM & $\begin{array}{l}\text { Lesion } \\
\text { size } \\
(\mathrm{mm})\end{array}$ & $\begin{array}{l}\text { Biopsy } \\
\text { plan } \\
\text { depth } \\
(\mathrm{mm})\end{array}$ & $\begin{array}{l}\text { Nr. of } \\
\text { biopsies }\end{array}$ & $\begin{array}{l}\text { Diagnostic } \\
\text { biopsy }\end{array}$ & $\begin{array}{l}\text { Gross } \\
\text { pathology }\end{array}$ & $\begin{array}{l}\text { Lesion } \\
\text { localization }\end{array}$ & Diagnosis & Outcome \\
\hline 1 & Dog & $\begin{array}{l}\text { Boston } \\
\text { Terrier }\end{array}$ & 10 & $\mathrm{~F}$ & 11 & PM & 19.7 & 38.2 & 2 & Yes & Yes & $\begin{array}{l}\text { Intra- } \\
\text { axial, } \\
\text { multifocal } \\
\text { parietal, } \\
\text { temporal, } \\
\text { occipital } \\
\text { and left } \\
\text { thalamus }\end{array}$ & $\begin{array}{l}\text { Anaplastic } \\
\text { astrocytoma } \\
\text { (WHO } \\
\text { Grade III) }\end{array}$ & \\
\hline 2 & Dog & $\begin{array}{l}\text { Portuguese } \\
\text { Water } \\
\text { Dog }\end{array}$ & 5 & FS & 26 & PM & 16.2 & 46.5 & 3 & Yes & No & $\begin{array}{l}\text { Intra- } \\
\text { axial, } \\
\text { bilateral } \\
\text { multifocal } \\
\text { forebrain } \\
\text { and } \\
\text { brainstem }\end{array}$ & $\begin{array}{l}\text { Necrotising } \\
\text { encephalitis }\end{array}$ & \\
\hline 3 & Dog & Boxer & 6 & M & 35 & IV & 20.6 & 49.6 & 5 & Yes & No & $\begin{array}{l}\text { Intra- } \\
\text { and } \\
\text { extra- } \\
\text { axial, left } \\
\text { temporal } \\
\text { lobe and } \\
\text { left } \\
\text { ventricle }\end{array}$ & Oligodendroglioma & Discharged \\
\hline 4 & Dog & $\begin{array}{l}\text { Bolonka } \\
\text { Zwetna }\end{array}$ & 5 & FS & 4 & PM & 26.2 & 31 & 2 & Yes & Yes & $\begin{array}{l}\text { Intra- } \\
\text { axial, } \\
\text { right } \\
\text { frontal } \\
\text { lobe }\end{array}$ & $\begin{array}{l}\text { Anaplastic } \\
\text { oligodendroglioma } \\
\text { (WHO } \\
\text { Grade III) }\end{array}$ & \\
\hline 5 & Dog & $\begin{array}{l}\text { French } \\
\text { Bulldog }\end{array}$ & 7 & FS & 10.1 & IV & 13.5 & 47.9 & 5 & Yes & No & $\begin{array}{l}\text { Intra- } \\
\text { and } \\
\text { extra- } \\
\text { axial, } \\
\text { right } \\
\text { temporal } \\
\text { lobe and } \\
\text { right } \\
\text { lateral } \\
\text { ventricle }\end{array}$ & $\begin{array}{l}\text { Anaplastic } \\
\text { oligodendroglioma } \\
\text { (WHO } \\
\text { Grade III) }\end{array}$ & Discharged \\
\hline
\end{tabular}


TABLE 1 | Continued

\begin{tabular}{|c|c|c|c|c|c|c|c|c|c|c|c|c|c|c|}
\hline $\begin{array}{l}\text { Pat. } \\
\text { Nr. }\end{array}$ & Species & Breed & $\begin{array}{l}\text { Age } \\
\text { (y) }\end{array}$ & Sex & $\begin{array}{l}\text { Body } \\
\text { weight } \\
\text { (kg) }\end{array}$ & IV/PM & $\begin{array}{l}\text { Lesion } \\
\text { size } \\
(\mathrm{mm})\end{array}$ & $\begin{array}{l}\text { Biopsy } \\
\text { plan } \\
\text { depth } \\
(\mathrm{mm})\end{array}$ & $\begin{array}{l}\text { Nr. of } \\
\text { biopsies }\end{array}$ & $\begin{array}{l}\text { Diagnostic } \\
\text { biopsy }\end{array}$ & $\begin{array}{l}\text { Gross } \\
\text { pathology }\end{array}$ & $\begin{array}{l}\text { Lesion } \\
\text { localization }\end{array}$ & Diagnosis & Outcome \\
\hline 6 & Cat & $\begin{array}{l}\text { British } \\
\text { Shorthair }\end{array}$ & 17 & FS & 4.8 & IV & 13.9 & 17.4 & 3 & Yes & No & $\begin{array}{l}\text { Intra- } \\
\text { axial, left } \\
\text { temporal } \\
\text { lobe }\end{array}$ & $\begin{array}{l}\text { Diffuse } \\
\text { astrocytoma } \\
\text { (WHO } \\
\text { Grade II) }\end{array}$ & Euthanasia \\
\hline 7 & Dog & $\begin{array}{l}\text { Mixed } \\
\text { breed }\end{array}$ & 8 & $\mathrm{MN}$ & 19 & PM & 18.2 & 47.6 & 3 & Yes & Yes & $\begin{array}{l}\text { Intra- } \\
\text { axial and } \\
\text { extra- } \\
\text { axial, left } \\
\text { cerebellar } \\
\text { hemisphere, } \\
\text { left lateral } \\
\text { and } \\
\text { fourth } \\
\text { ventricles }\end{array}$ & $\begin{array}{l}\text { Choroid } \\
\text { plexus } \\
\text { carcinoma }\end{array}$ & \\
\hline 8 & Dog & $\begin{array}{l}\text { Mixed } \\
\text { breed }\end{array}$ & 10 & $\mathrm{MN}$ & 6.9 & PM & 16.3 & 30.2 & 4 & Yes & Yes & $\begin{array}{l}\text { Intra- } \\
\text { axial, } \\
\text { right } \\
\text { thalamus } \\
\text { and } \\
\text { mesencephalon }\end{array}$ & $\begin{array}{l}\text { Anaplastic } \\
\text { oligodendroglioma } \\
\text { (WHO } \\
\text { Grade III) }\end{array}$ & \\
\hline 9 & Cat & Birman & 5 & FS & 3.7 & PM & 15.3 & 32.5 & 4 & Yes & Yes & $\begin{array}{l}\text { Intra- } \\
\text { axial, } \\
\text { mesencephalon } \\
\text { and } \\
\text { metencephalon }\end{array}$ & $\begin{array}{l}\text { Anaplastic } \\
\text { oligodendroglioma } \\
\text { (WHO } \\
\text { Grade III) }\end{array}$ & \\
\hline 10 & Dog & $\begin{array}{l}\text { Labrador } \\
\text { Retriever }\end{array}$ & 11 & $\mathrm{MN}$ & 29.4 & PM & 14.8 & 57.1 & 4 & Yes & Yes & $\begin{array}{l}\text { Extra- } \\
\text { axial, left } \\
\text { lateral } \\
\text { ventricle }\end{array}$ & $\begin{array}{l}\text { Choroid } \\
\text { plexus } \\
\text { carcinoma }\end{array}$ & \\
\hline 11 & Dog & $\begin{array}{l}\text { Golden } \\
\text { Retriever }\end{array}$ & 6 & M & 40.1 & PM & 20.2 & 28.5 & 4 & Yes & Yes & $\begin{array}{l}\text { Intra- } \\
\text { axial, left } \\
\text { thalamus }\end{array}$ & $\begin{array}{l}\text { Hystiocytic } \\
\text { sarcoma }\end{array}$ & \\
\hline 12 & Dog & $\begin{array}{l}\text { Shih } \\
\text { Tzu }\end{array}$ & 10 & FS & 8.9 & PM & 18.8 & 23.4 & 3 & Yes & Yes & $\begin{array}{l}\text { Intra- } \\
\text { axial, left } \\
\text { temporal } \\
\text { lobe }\end{array}$ & $\begin{array}{l}\text { Cystic } \\
\text { metastatic } \\
\text { carcinoma }\end{array}$ & \\
\hline 13 & Dog & Poodle & 11 & FS & 9.5 & PM & 13.8 & 37.2 & 3 & Yes & Yes & $\begin{array}{l}\text { Intra- } \\
\text { axial, } \\
\text { bilateral } \\
\text { multifocal } \\
\text { forebrain }\end{array}$ & $\begin{array}{l}\text { Vasculitis } \\
\text { and } \\
\text { meningoencephalitis } \\
\text { of unknown } \\
\text { origin }\end{array}$ & \\
\hline
\end{tabular}




\begin{tabular}{|c|c|c|c|c|c|c|c|c|c|c|c|c|c|c|}
\hline $\begin{array}{l}\text { Pat. } \\
\text { Nr. }\end{array}$ & Species & Breed & $\begin{array}{l}\text { Age } \\
\text { (y) }\end{array}$ & Sex & $\begin{array}{l}\text { Body } \\
\text { weight } \\
\text { (kg) }\end{array}$ & IV/PM & $\begin{array}{l}\text { Lesion } \\
\text { size } \\
(\mathrm{mm})\end{array}$ & $\begin{array}{l}\text { Biopsy } \\
\text { plan } \\
\text { depth } \\
(\mathrm{mm})\end{array}$ & $\begin{array}{l}\text { Nr. of } \\
\text { biopsies }\end{array}$ & $\begin{array}{l}\text { Diagnostic } \\
\text { biopsy }\end{array}$ & $\begin{array}{l}\text { Gross } \\
\text { pathology }\end{array}$ & $\begin{array}{l}\text { Lesion } \\
\text { localization }\end{array}$ & Diagnosis & Outcome \\
\hline 14 & Dog & $\begin{array}{l}\text { Magyar } \\
\text { Viszla }\end{array}$ & 1 & M & 26.2 & IV & 21.7 & 37.2 & 4 & Yes & Yes & $\begin{array}{l}\text { Intra- } \\
\text { and } \\
\text { extra- } \\
\text { axial, } \\
\text { right } \\
\text { thalamus } \\
\text { and right } \\
\text { lateral } \\
\text { ventricle }\end{array}$ & $\begin{array}{l}\text { Meningioma } \\
\text { and } \\
\text { Meningoangiomatosi }\end{array}$ & $\begin{array}{l}\text { Euthanasia } \\
\text { sis }\end{array}$ \\
\hline 15 & Dog & Collie & 10 & M & 20 & IV & 20.9 & 20.1 & 6 & Yes & No & $\begin{array}{l}\text { Extra- } \\
\text { axial, } \\
\text { right } \\
\text { rostral } \\
\text { cranial } \\
\text { fossa, } \\
\text { extracranial } \\
\text { extension }\end{array}$ & $\begin{array}{l}\text { Transitional } \\
\text { meningioma } \\
\text { (WHO } \\
\text { Grade I) }\end{array}$ & Euthanasia \\
\hline 16 & Dog & $\begin{array}{l}\text { Border } \\
\text { Terrier }\end{array}$ & 8 & $\mathrm{~F}$ & 10.8 & PM & 12.7 & 35.9 & 4 & Yes & Yes & $\begin{array}{l}\text { Intra- } \\
\text { axial, left } \\
\text { frontal } \\
\text { lobe }\end{array}$ & $\begin{array}{l}\text { Anaplastic } \\
\text { oligodendroglioma } \\
\text { (WHO } \\
\text { Grade III) }\end{array}$ & \\
\hline 17 & Dog & $\begin{array}{l}\text { French } \\
\text { Bulldog }\end{array}$ & 4 & $\mathrm{~F}$ & 10.8 & PM & 19.5 & 37.8 & 4 & Yes & Yes & $\begin{array}{l}\text { Intra- } \\
\text { axial, } \\
\text { right } \\
\text { frontal } \\
\text { lobe }\end{array}$ & $\begin{array}{l}\text { Anaplastic } \\
\text { oligodendroglioma } \\
\text { (WHO } \\
\text { Grade III) }\end{array}$ & \\
\hline 18 & Dog & $\begin{array}{l}\text { Bolonka } \\
\text { Zwetna }\end{array}$ & 8 & $\mathrm{MN}$ & 7.9 & PM & 23.6 & 34.3 & 6 & Yes & No & $\begin{array}{l}\text { Intra- } \\
\text { and } \\
\text { extra- } \\
\text { axial, left } \\
\text { frontal } \\
\text { lobe }\end{array}$ & $\begin{array}{l}\text { Atypical } \\
\text { meningioma } \\
\text { (WHO } \\
\text { Grade II) }\end{array}$ & \\
\hline 19 & Dog & $\begin{array}{l}\text { French } \\
\text { Bulldog }\end{array}$ & 5 & M & 15.5 & PM & 25.9 & 27.8 & 4 & Yes & Yes & $\begin{array}{l}\text { Intra- } \\
\text { and } \\
\text { extra- } \\
\text { axial, left } \\
\text { frontal } \\
\text { lobe and } \\
\text { left lateral } \\
\text { ventricle }\end{array}$ & $\begin{array}{l}\text { Oligodendroglioma } \\
\text { (WHO } \\
\text { Grade III) }\end{array}$ & \\
\hline
\end{tabular}




\begin{tabular}{|c|c|c|c|c|c|c|c|c|c|c|c|c|c|c|}
\hline $\begin{array}{l}\text { Pat. } \\
\text { Nr. }\end{array}$ & Species & Breed & $\begin{array}{l}\text { Age } \\
\text { (y) }\end{array}$ & Sex & $\begin{array}{l}\text { Body } \\
\text { weight } \\
\text { (kg) }\end{array}$ & IV/PM & $\begin{array}{l}\text { Lesion } \\
\text { size } \\
(\mathrm{mm})\end{array}$ & $\begin{array}{l}\text { Biopsy } \\
\text { plan } \\
\text { depth } \\
(\mathrm{mm})\end{array}$ & $\begin{array}{l}\text { Nr. of } \\
\text { biopsies }\end{array}$ & $\begin{array}{l}\text { Diagnostic } \\
\text { biopsy }\end{array}$ & $\begin{array}{l}\text { Gross } \\
\text { pathology }\end{array}$ & $\begin{array}{l}\text { Lesion } \\
\text { localization }\end{array}$ & Diagnosis & Outcome \\
\hline 20 & Cat & $\begin{array}{l}\text { European } \\
\text { shorthair }\end{array}$ & 7 & FS & 6 & PM & 12.1 & 28.2 & 3 & Yes & Yes & $\begin{array}{l}\text { Extra- } \\
\text { axial, left } \\
\text { rostral } \\
\text { cranial } \\
\text { fossa, } \\
\text { extracranial } \\
\text { extension }\end{array}$ & Sarcoma & \\
\hline 21 & Dog & $\begin{array}{l}\text { Bernese } \\
\text { Mountain } \\
\text { Dog }\end{array}$ & 6 & M & 55 & PM & 15 & 58.2 & 3 & Yes & Yes & $\begin{array}{l}\text { Intra- } \\
\text { axial, } \\
\text { bilateral } \\
\text { multifocal } \\
\text { forebrain }\end{array}$ & $\begin{array}{l}\text { Granulomatous } \\
\text { and } \\
\text { necrotizing } \\
\text { meningoencephalitis }\end{array}$ & \\
\hline 22 & Dog & $\begin{array}{l}\text { Mixed } \\
\text { breed }\end{array}$ & 12 & $\mathrm{MN}$ & 40 & PM & 11 & 55.4 & 3 & Yes & No & $\begin{array}{l}\text { Extra- } \\
\text { axial, left } \\
\text { lateral } \\
\text { ventricle }\end{array}$ & $\begin{array}{l}\text { Choroid } \\
\text { plexus-tumor } \\
\text { (unclassified } \\
\text { grade) }\end{array}$ & \\
\hline 23 & Dog & Boxer & 7 & FS & 26 & PM & 32.6 & 47.5 & 4 & Yes & Yes & $\begin{array}{l}\text { Intra- } \\
\text { axial, } \\
\text { right } \\
\text { temporal } \\
\text { lobe }\end{array}$ & $\begin{array}{l}\text { Oligodendroglioma } \\
\text { (WHO } \\
\text { Grade II) }\end{array}$ & \\
\hline 24 & Dog & Boxer & 1 & M & 24 & PM & 22.7 & 60 & 3 & No & No & $\begin{array}{l}\text { Intra- } \\
\text { axial, left } \\
\text { temporal } \\
\text { lobe }\end{array}$ & $\begin{array}{l}\text { Anaplastic } \\
\text { oligodendroglioma } \\
\text { (WHO } \\
\text { Grade III) }\end{array}$ & \\
\hline 25 & Dog & $\begin{array}{l}\text { German } \\
\text { shepherd }\end{array}$ & 9 & FS & 32 & IV & 18.8 & 20.8 & 2 & Yes & No & $\begin{array}{l}\text { Intra- } \\
\text { axial, left } \\
\text { cerebellar } \\
\text { hemisphere }\end{array}$ & $\begin{array}{l}\text { Diffuse } \\
\text { astrocytoma } \\
\text { (WHO } \\
\text { Grade II) }\end{array}$ & Discharged \\
\hline 26 & Dog & Dachshund & 6 & M & 6.5 & PM & 14 & 53 & 4 & Yes & Yes & $\begin{array}{l}\text { Intra- } \\
\text { axial, } \\
\text { right } \\
\text { thalamus }\end{array}$ & $\begin{array}{l}\text { Granulomatous } \\
\text { encephalitis } \\
\text { and } \\
\text { vasculitis }\end{array}$ & \\
\hline 27 & Cat & $\begin{array}{l}\text { European } \\
\text { Shorthair }\end{array}$ & 13 & FS & 4 & PM & 11.7 & 46.1 & 4 & Yes & No & $\begin{array}{l}\text { Extra- } \\
\text { axial, } \\
\text { sella }\end{array}$ & $\begin{array}{l}\text { Chromophobe } \\
\text { hypophyseal } \\
\text { adenoma }\end{array}$ & \\
\hline 28 & Dog & $\begin{array}{l}\text { Golden } \\
\text { Retriever }\end{array}$ & 8 & FS & 27 & IV & 18.4 & 43.1 & 3 & Yes & No & $\begin{array}{l}\text { Intra- } \\
\text { axial, } \\
\text { right } \\
\text { occipital } \\
\text { lobe }\end{array}$ & $\begin{array}{l}\text { Unspecific } \\
\text { lymphoplasmacytic } \\
\text { encephalitis }\end{array}$ & Discharged \\
\hline
\end{tabular}

Pat., patient; Nr., number; F, female; FS, female spayed; $M$, male; MN, male neutered; y, years; kg, kilogram; IV, intra vitam; PM, post mortem; MRI, magnetic resonance imaging; CT, computed tomography; mm, millimeters; WHO, World Health Organization. 


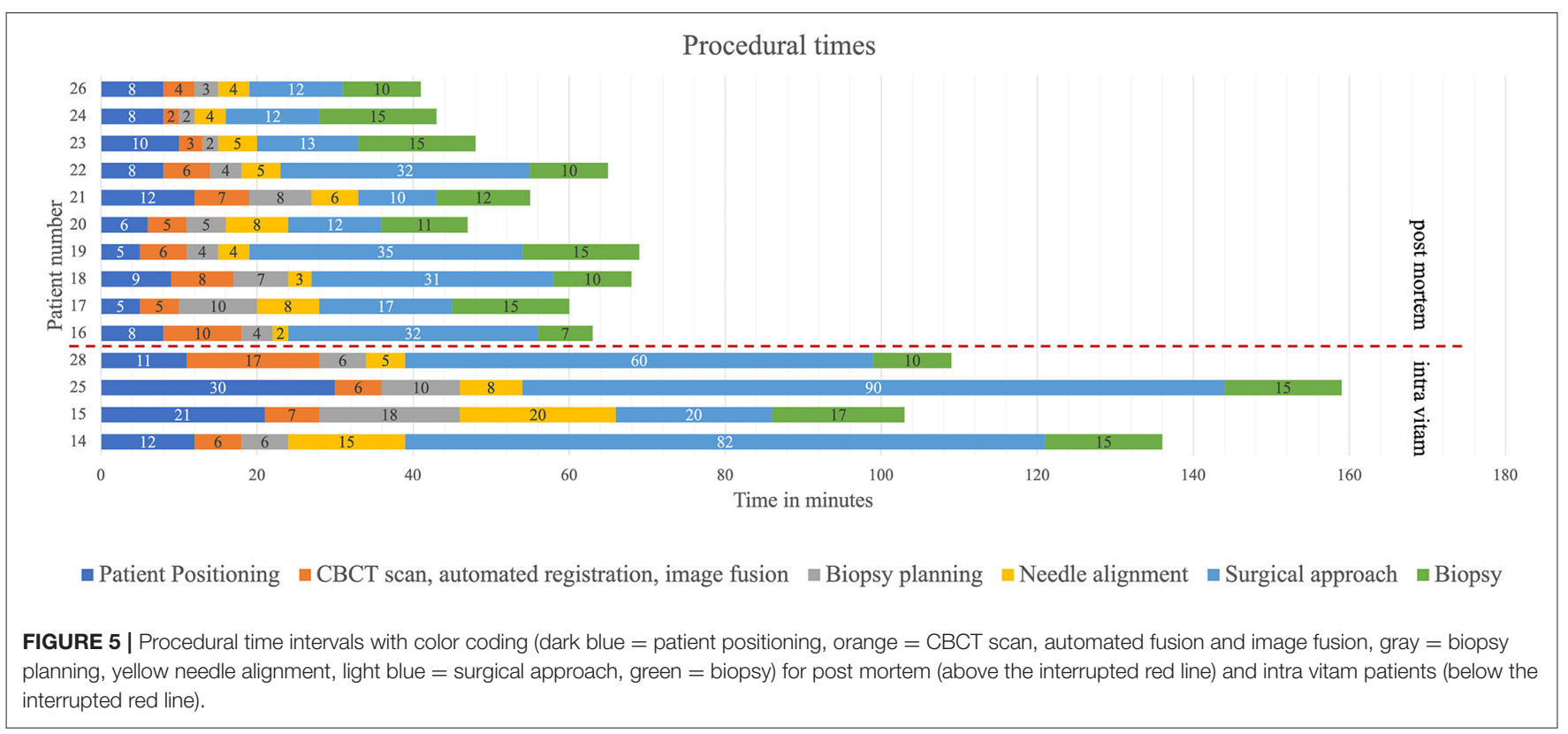

successfully implemented in cranial and spinal interventions in people and recently for orthopedic interventions in equines (24). Cranial interventions are reported for endonasal surgeries of the skull base, hypophysectomy, and electrode placement for deep brain stimulation $(32,33)$. The reported Euclidean vector error between 1.59 and 2.16 for electrode placement is similar to the median needle placement error obtained in the present study (25). Considering the maximum needle placement error of $2.84 \mathrm{~mm}$ we obtained in one dog, diagnostic biopsies can be obtained from lesions with diameters as small as $5.7 \mathrm{~mm}$. Such target accuracies are usually acceptable for brain biopsy samples in veterinary medicine with reported values ranging from 0.9 to $4.3 \mathrm{~mm}$ using a variety of frame-based and frameless systems $(17,20,21,34)$. The intraoperative CBCTbased automated registration system for frameless brain biopsies used in the present study can therefore be considered a valid alternative approach.

Apart from target accuracy, diagnostic yield and diagnostic accuracy are the most important criteria to evaluate success of brain biopsies. In the present study, the diagnostic yield was $96.4 \%$ and the diagnostic accuracy was $94.4 \%$. These results compare favorably with the limited data available in veterinary medicine (35) where the diagnostic yield varies between 82 to $100 \%$ for free-hand and frame-based biopsies in dogs with encephalitis $(10,36)$, and from 81 to $94.6 \%$ in dogs with neoplastic disease and frame-based systems $(10,17,19)$. Diagnostic accuracy has been reported to range from $13 \%$ using a free-hand biopsy technique (37), to $81 \%$ (19) and $91 \%$ (10), and therefore we consider the reported system to be adequate. The single non-diagnostic sample consisted of mucinous fluid and the sample was insufficient for diagnosis. This dog was subsequently diagnosed as a grade III oligodendroglioma on necropsy. The failure to deliver adequate amounts of tissue was attributed to the inability to preserve the integrity of the gelatinous tumor matrix despite use of a nylon mesh biopsy bag and a biopsy cassette rather than needle placement error. Similarly, in another dog (patient number three) a diagnosis of oligodendroglioma could be made, but sample quality was insufficient for grading. In the remaining cases diagnostic biopsies could be retrieved even in poorly accessible locations such as deep-seated mid-line, brainstem, and cerebellar sites. Lesion size, depth, location, and number of biopsies did not have an effect on diagnostic yield or diagnostic accuracy.

Still considered the standard of care due to its excellent accuracy, the use of frame-based systems in veterinary patients has disadvantages resulting from the bulky frame that needs to be firmly attached to the skull. Large differences in skull size, morphology, and thickness of the masticatory musculature among different canine breeds and small skull size among felines poses a challenge and there is a need for simpler, less time consuming, and safe alternatives. A recently developed method utilizing 3D printed brain personalized biopsy devices ingenuously addresses variable skull morphology and size but still requires an additional anesthesia for surgical implantation of superficial bone anchors before the actual biopsy procedure $(20,38)$. The intraoperative imaging capability of the mobile $\mathrm{CBCT}$ unit has the advantage that after the initial diagnostic MRI scan, further imaging and biopsy procedures are performed during the same anesthesia. Target planning can be performed as soon as the MRI sequence is loaded onto the workstation and modified at any time during the procedure as needed. The automatic image fusion of the CBCT volume with the MRI sequence worked reliably, and since the patient reference array and reflecting markers on the $\mathrm{CBCT}$ unit are recognized by the workstation's infrared camera, no manual patient registration is necessary after volume acquisition. These features eliminate two possible sources of error and potentially reduce procedural time. In the present study median total procedural time in 
alive patients was $122.5 \mathrm{~min}$ and therefore within the range of previously reported duration times of $60-240 \mathrm{~min}(10,11,17)$. Because time savings associated with frameless stereotaxy have been supported by numerous studies $(39,40)$, we expected even shorter procedural times. The surgeon's lack of experience and training, both crucial factors to short procedural times, might explain some of the delay (10). Indeed, we noticed a shortening of procedural time with increasing experience for postmortem biopsies from 69 to $41 \mathrm{~min}$. We expect analysis of a larger number of both intra vitam and post mortem procedures with the present system to reveal time savings more clearly. Comparison of brain biopsy procedural times in companion animals is problematic as published data generally do not clearly define start and endpoints $(10,11,17,21)$, or consider time spent on preparatory imaging, which is often done on separate days. For example, if defined as incision-to-end of biopsy retrieval median procedural times for intra vitam and post mortem procedures would be as low as 78.5 and $30 \mathrm{~min}$, respectively, in this study. We opted to report individual time intervals and computed total procedural time by adding individual time intervals to provide a better overview knowing that comparison with previous studies would be difficult at best.

The low case numbers of alive dogs and cats precluded evaluation of experience on intra vitam procedural times. The difference between post mortem compared to intra vitam biopsy procedure times is thought to be due to easier instrument and animal handling.

\section{Limitations}

The present study has several limitations. Target accuracy was based on repeatedly merged images with the biopsy needle in place as described before. The inevitable metal artifacts due to beam hardening on post-operative images were considered acceptable to determine the needle tip location but may have introduced minor inaccuracies. Differences in registration and fusion accuracy when, respectively, merging MRI, CBCT, or $\mathrm{CT}$ with intraoperative CBCT cannot be excluded. Additionally, the influence of system inherent, registration, and fusion errors could not be assessed since the details of the image registration and fusion algorithms are not publicly known for commercial proprietary software packages. Needle placement error might therefore ultimately be considered as the summation of these factors in addition to mechanical alignment error. However, the needle placement error determined in the present study is

\section{REFERENCES}

1. Rossmeisl JH. New treatment modalities for brain tumors in dogs and cats. Vet Clin North Am Small Anim Pract. (2014) 44:101338. doi: 10.1016/j.cvsm.2014.07.003

2. Dickinson PJ. Advances in diagnostic and treatment modalities for intracranial tumors. J Vet Intern Med. (2014) 28:116585. doi: $10.1111 /$ jvim. 12370

3. Cervera V, Mai W, Vite CH, Johnson V, Dayrell-Hart B, Seiler GS. Comparative magnetic resonance imaging findings between gliomas and presumed cerebrovascular accidents in dogs. Vet Radiol Ultrasound. (2011) 52:33-40. doi: 10.1111/j.1740-8261.2010.01749.x in keeping with previously reported target accuracies in both phantom and clinical studies in people undergoing deep brain stimulation using this system ranging between 0.75 and $1.68 \mathrm{~mm}$ (41). Procedural times were not measured in all patients because spatial constraints imposed by operating room size and geometry as well as the need to accommodate anesthetic equipment and additional personnel required adjustments in the disposition of the CBCT, the workstation, as well as of the articulating instrument holder on the surgical table during the first three intra vitam brain biopsy procedures. Besides uneven sample sizes, meaningful statistical comparison between intra vitam and post mortem groups was further hampered by variable skull size, morphology, and lesion location.

\section{CONCLUSION}

In conclusion, the use of mobile intraoperative CBCT-based registration combined with neuronavigation for frameless brain biopsies in companion animals showed to be an efficient method to sample brain tissue with a good target accuracy, diagnostic yield and diagnostic accuracy independent on skull size and morphology. Studies including a larger number of patients are needed to investigate potential time savings compared to previously published brain biopsy systems.

\section{DATA AVAILABILITY STATEMENT}

The original contributions presented in the study are included in the article/supplementary material, further inquiries can be directed to the corresponding author/s.

\section{ETHICS STATEMENT}

Ethical review and approval was not required for the animal study because the study was performed in agreement with the local ethical regulations. Written informed consent was obtained from the owners for the participation of their animals in this study.

\section{AUTHOR CONTRIBUTIONS}

FM and DS conception and design of the study. FM, AM, AO, and DS-G data acquisition. FF neurosurgical management. FM drafting of the manuscript. All authors contributed to the article and approved the submitted version.
4. Wolff CA, Holmes SP, Young BD, Chen AV, Kent M, Platt SR, et al. Magnetic resonance imaging for the differentiation of neoplastic, inflammatory, and cerebrovascular brain disease in dogs. J Vet Intern Med. (2012) 26:58997. doi: 10.1111/j.1939-1676.2012.00899.x

5. Diangelo L, Cohen-Gadol A, Heng HG, Miller MA, Hague DW, Rossmeisl $\mathrm{JH}$, et al. Glioma mimics: magnetic resonance imaging characteristics of granulomas in dogs. Front Vet Sci. (2019) 6:286. doi: 10.3389/fvets.2019.00286

6. Arbit E, Galicich JH. Importance of image-guided stereotactic biopsy to confirm diagnosis in an oncological setting. Ann Surg Oncol. (1994) 1:36872. doi: $10.1007 / \mathrm{BF} 02303807$

7. Callovini GM. Is it appropriate to redefine the indication for stereotactic brain biopsy in the MRI Era? Correlation with final histological diagnosis 
in supratentorial gliomas. Minim Invasive Neurosurg. (2008) 51:10913. doi: $10.1055 / \mathrm{s}-2008-1058096$

8. Friedman WA, Sceats Jr DJ, Nestok BR, Ballinger Jr WE. The incidence of unexpected pathological findings in an image-guided biopsy series: a review of 100 consecutive cases. Neurosurgery. (1989) 25:180-4. doi: 10.1227/00006123-198908000-00005

9. LeCouteur RA. Current concepts in the diagnosis and treatment of brain tumours in dogs and cats. J Small Anim Pract. (1999) 40:4116. doi: 10.1111/j.1748-5827.1999.tb03113.x

10. Koblik PD, LeCouteur RA, Higgins RJ, Bollen AW, Vernau KM, Kortz GD, et al. CT-guided brain biopsy using a modified pelorus mark III stereotactic system: experience with 50 dogs. Vet Radiol Ultrasound. (1999) 40:43440. doi: 10.1111/j.1740-8261.1999.tb00371.x

11. Moissonnier P, Blot S, Devauchelle P, Delisle F, Beuvon F, Boulha L, et al. Stereotactic CT-guided brain biopsy in the dog. J Small Anim Pract. (2002) 43:115-23. doi: 10.1111/j.1748-5827.2002.tb00041.x

12. Flegel T, Podell M, March PA, Chakeres DW. Use of a disposable real-time CT stereotactic navigator device for minimally invasive dog brain biopsy through a mini-burr hole. AJNR Am J Neuroradiol. (2002) 23:1160-3.

13. Koblik PD, LeCouteur RA, Higgins RJ, Fick J, Kortz GD, Sturges BK, et al. Modification and application of a pelorus mark III stereotactic system for CT-guided brain biopsy in 50 dogs. Vet Radiol Ultrasound. (1999) 40:42433. doi: 10.1111/j.1740-8261.1999.tb00370.x

14. Giroux A, Jones JC, Bøhn JH, Duncan RB, Waldron DR, Inzana KR. A new device for stereotactic CT-guided biopsy of the canine brain: design, construction, and needle placement accuracy. Vet Radiol Ultrasound. (2002) 43:229-36. doi: 10.1111/j.1740-8261.2002.tb0 0995.x

15. Taylor AR, Cohen ND, Fletcher S, Griffin JF, Levine JM. Application and machine accuracy of a new frameless computed tomography-guided stereotactic brain biopsy system in dogs. Vet Radiol Ultrasound. (2013) 54:332-42. doi: 10.1111/vru.12025

16. Squires AD, Gao Y, Taylor SF, Kent M, Tse ZT. A simple and inexpensive stereotactic guidance frame for MRI-guided brain biopsy in canines. J Med Eng. (2014) 2014:139535. doi: 10.1155/2014/139535

17. Rossmeisl JH, Andriani RT, Cecere TE, Lahmers $\mathrm{K}$, LeRoith $\mathrm{T}$, Zimmerman KL, et al. Frame-based stereotactic biopsy of canine brain masses: technique and clinical results in 26 cases. Front Vet Sci. (2015) 2:20. doi: $10.3389 /$ fvets. 2015.00020

18. Packer RA, Freeman LJ, Miller MA, Fauber AE, Morrison WB. Evaluation of minimally invasive excisional brain biopsy and intracranial brachytherapy catheter placement in dogs. Am J Vet Res. (2011) 72:109-21. doi: 10.2460/ajvr.72.1.109

19. Kani Y, Cecere TE, Lahmers K, LeRoith T, Zimmerman KL, Isom S, et al. Diagnostic accuracy of stereotactic brain biopsy for intracranial neoplasia in dogs: comparison of biopsy, surgical resection, and necropsy specimens. J Vet Intern Med. (2019) 33:1384-91. doi: 10.1111/jvim. 15500

20. Gutmann S, Winkler D, Müller M, Möbius R, Fischer JP, Böttcher $\mathrm{P}$, et al. Accuracy of a magnetic resonance imaging-based 3D printed stereotactic brain biopsy device in dogs. J Vet Intern Med. (2020) 34:84451. doi: $10.1111 /$ jvim. 15739

21. Troxel MT, Vite CH. CT-guided stereotactic brain biopsy using the Kopf stereotactic system. Vet Radiol Ultrasound. (2008) 49:438-43. doi: 10.1111/j.1740-8261.2008.00403.x

22. Dorward NL, Paleologos TS, Alberti O, Thomas DG. The advantages of frameless stereotactic biopsy over frame-based biopsy. Br J Neurosurg. (2002) 16:110-8. doi: 10.1080/02688690220131705

23. Maciunas RJ, Galloway Jr RL, Latimer JW. The application accuracy of stereotactic frames. Neurosurgery. (1994) 35:682-94; discussion 945. doi: 10.1097/00006123-199410000-00015

24. de Preux M, Klopfenstein Bregger MD, Brunisholz HP, Van der Vekens E, Schweizer-Gorgas D, Koch C. Clinical use of computer-assisted orthopedic surgery in horses. Vet Surg. (2020) 49:1075-87. doi: 10.1111/vsu.13486

25. Sharma M, Deogaonkar M. Accuracy and safety of targeting using intraoperative "O-arm" during placement of deep brain stimulation electrodes without electrophysiological recordings. J Clin Neurosci. (2016) 27:806. doi: 10.1016/j.jocn.2015.06.036

26. Carl B, Bopp M, Sass B, Nimsky C. Intraoperative computed tomography as reliable navigation registration device in 200 cranial procedures. Acta Neurochir. (2018) 160:1681-9. doi: 10.1007/s00701-018-3641-6
27. Louis DN, Ohgaki H, Wiestler OD, Cavenee WK, Burger PC, Jouvet A, et al. The 2007 WHO classification of tumours of the central nervous system. Acta Neuropathol. (2007) 114:97-109. doi: 10.1007/s00401-007-0243-4

28. Higgins RJ, Bollen AW, Dickinson PJ, Sisó-Llonch S. Tumors of the nervous system. Tumors Dom Ani. (2016) 834-91. doi: 10.1002/9781119181200.ch19

29. Merickel JL, Pluhar GE, Rendahl A, O'Sullivan MG. Prognostic histopathologic features of canine glial tumors. Vet Pathol. (2021) 58:945-51. doi: 10.1177/03009858211025795

30. Koehler JW, Miller AD, Miller CR, Porter B, Aldape K, Beck J, et al. A revised diagnostic classification of canine glioma: towards validation of the canine glioma patient as a naturally occurring preclinical model for human glioma. $J$ Neuropathol Exp Neurol. (2018) 77:1039-54. doi: 10.1093/jnen/nly085

31. Jackson RJ, Fuller GN, Abi-Said D, Lang FF, Gokaslan ZL, Shi WM, et al. Limitations of stereotactic biopsy in the initial management of gliomas. Neuro Oncol. (2001) 3:193-200. doi: 10.1093/neuonc/3.3.193

32. Banat M, Wach J, Salemdawod A, Bahna M, Scorzin J, Vatter H. The role of intraoperative image guidance systems (Three-Dimensional C-arm versus O-arm) in spinal surgery: results of a single-center study. World Neurosurg. (2021) 146:e817-21. doi: 10.1016/j.wneu.2020.11.013

33. Krahulik D, Nevrly M, Otruba P, Bardon J, Hrabalek L, Pohlodek D, et al. Oarm navigated frameless and fiducial-less deep brain stimulation. Brain Sci. (2020) 10:683. doi: 10.3390/brainsci10100683

34. Chen AV, Wininger FA, Frey S, Comeau RM, Bagley RS, Tucker RL, et al. Description and validation of a magnetic resonance imaging-guided stereotactic brain biopsy device in the dog. Vet Radiol Ultrasound. (2012) 53:150-6. doi: 10.1111/j.1740-8261.2011.01889.x

35. Dhawan S, He Y, Bartek Jr J, Alattar AA, Chen CC. Comparison of frame-based versus frameless intracranial stereotactic biopsy: systematic review and meta-analysis. World Neurosurg. (2019) 127:607-16.e4. doi: 10.1016/j.wneu.2019.04.016

36. Flegel T, Oevermann A, Oechtering G, Matiasek K. Diagnostic yield and adverse effects of MRI-guided free-hand brain biopsies through a miniburr hole in dogs with encephalitis. J Vet Intern Med. (2012) 26:96976. doi: 10.1111/j.1939-1676.2012.00961.x

37. Harari J, Moore M, Leathers C, Roberts G, Gavin P. Computed tomographicguided, free-hand needle biopsy of brain tumors in dogs. Prog Vet Neurol. (1993) 4:41-4.

38. Müller M, Winkler D, Möbius R, Sauerstein T, Scholz S, Gutmann S, et al. A concept for a 3D-printed patient-specific stereotaxy platform for brain biopsy -a canine cadaver study. Res Vet Sci. (2019) 124:7984. doi: 10.1016/j.rvsc.2019.02.007

39. Grunert P, Espinosa J, Busert C, Günthner M, Filippi R, Farag S, et al. Stereotactic biopsies guided by an optical navigation system: technique and clinical experience. Minim Invasive Neurosurg. (2002) 45:115. doi: $10.1055 / \mathrm{s}-2002-23576$

40. Dammers R, Haitsma IK, Schouten JW, Kros JM, Avezaat CJ, Vincent AJ. Safety and efficacy of frameless and frame-based intracranial biopsy techniques. Acta Neurochir. (2008) 150:23-9. doi: 10.1007/s00701-007-1473-x

41. Katisko JP, Kauppinen MT, Koivukangas JP, Heikkinen ER. Stereotactic operations using the o-arm. Stereotact Funct Neurosurg. (2012) 90:4019. doi: $10.1159 / 000341699$

Conflict of Interest: The authors declare that the research was conducted in the absence of any commercial or financial relationships that could be construed as a potential conflict of interest.

Publisher's Note: All claims expressed in this article are solely those of the authors and do not necessarily represent those of their affiliated organizations, or those of the publisher, the editors and the reviewers. Any product that may be evaluated in this article, or claim that may be made by its manufacturer, is not guaranteed or endorsed by the publisher.

Copyright (๑) 2022 Meneses, Maiolini, Forterre, Oevermann and Schweizer-Gorgas. This is an open-access article distributed under the terms of the Creative Commons Attribution License (CC BY). The use, distribution or reproduction in other forums is permitted, provided the original author(s) and the copyright owner(s) are credited and that the original publication in this journal is cited, in accordance with accepted academic practice. No use, distribution or reproduction is permitted which does not comply with these terms. 